\title{
Exploring Host Community Perception of Panchor Town for Tourist Destination based on Social Exchange Theory
}

\author{
Mazni Saad, Nur Nabilah Abdullah², Siti Nur Hidayah Rosman ${ }^{3}$
}

${ }^{1}$ Department of Tourism, ${ }^{2}$ Department of English

Department of English, Kulliyyah of Languages and Management, Kulliyyah of Languages and Management, International Islamic University Malaysia, Edu Hub Pagoh, KM1, Jalan Panchor,

Pagoh 84600 Muar, Johor, Malaysia

maznisaad@iium.edu.my, nnabila@iium.edu.my, cthidayahrosman@gmail.com

Tel: 60178787543

\begin{abstract}
This paper explores the significance of a rural region, the village of Panchor, as a potential nature tourism site located in Johor district of Muar, Malaysia. The study's objectives were (1) evaluating local community funding, and (2) evaluating the participation of local government. Three overlapping topics were explored based on qualitative interpretation of an interview and open-ended answers in the questionnaire: (1) group connection, (2) economic benefits, and (3) environmental attitude. The findings revealed that river-based tourism could improve the socio-economic status and the sustainability of rural areas. It also addressed the consequences and limitations of the study in this report.
\end{abstract}

Keywords: Community Attachment; Economic Gains; Environmental Attitude; River-based Tourism

eISSN: 2398-4295 @ 2020. The Authors. Published for AMER ABRA cE-Bs by e-International Publishing House, Ltd., UK. This is an open access article under the CC BY-NC-ND license (http://creativecommons.org/licenses/by-nc-nd/4.0/). Peer-review under responsibility of AMER (Association of Malaysian Environment-Behaviour Researchers), ABRA (Association of Behavioural Researchers on Asians / Africans / Arabians) and cE-Bs (Centre for Environment-Behaviour Studies), Faculty of Architecture, Planning \& Surveying, Universiti Teknologi MARA, Malaysia.

DOI: https://doi.org/10.21834/ajbes.v5i19.191 


\subsection{Introduction}

The natural resources of rivers manifest both natural beauty and usefulness for a vast array of human activities including river-based tourism such as river cruises, fishing, boating, and other forms of tourism activities (Laws \& Sermone, 2009). The Muar River plays a key role in Malaysia's history, culture, and economy. Hence, the Muar district in Johor has made an enormous effort to increase its tourism potential with an attractive new tourism product, such as potential river tourism in the Panchor rural area strategically located next to the Muar River. It is no doubt that the potential river-based tourism may contribute to Johor state's foreign income and the Panchor local community's economic status. Nevertheless, issues related to the local community's socioeconomic well-being, support and involvement need to be taken into account.

Johor state aims to become a high-value regional tourism destination by 2023 (Benjamin, 2018), an ambition associated with the 2014-2023 Master Plan for Johor Tourism. Since its goal is to increase tourist arrivals from domestic and foreign countries to Johor, Muar district has stepped up efforts to optimize its tourism potential with an attractive new tourism product. Muar, a popular tourist destination already $p$ boasts well-preserved pre-historic houses, a fascinating history, and fine cuisine. Muar highlights its strategic position at the mouth of Muar River. Panchor covers an estimated area of 40.6 hectares and is about 40 kilometres from the town of Muar (see Fig. 1) in a new plan for the rural town of Panchor to establish tourism on the river. According to Rahman et al. (2020) and Shah (2018), this is potentially the result of tourism that could help Muar achieve its target of tourism growth.

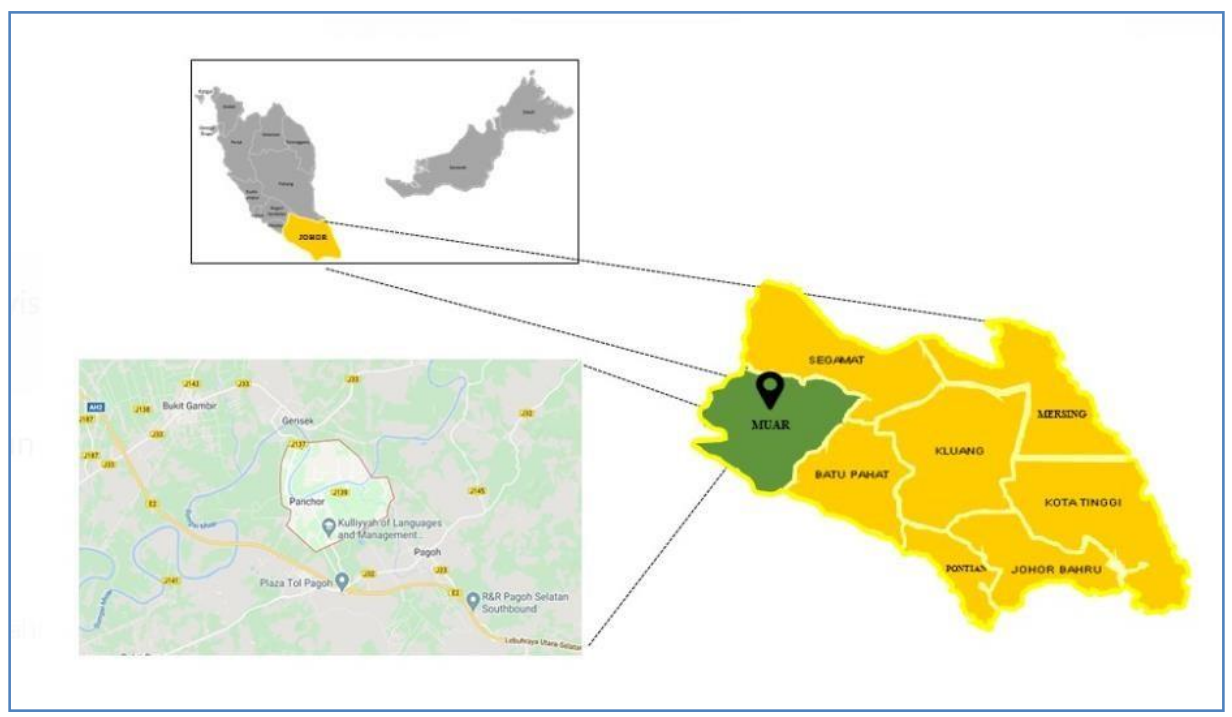

Fig. 1: Geographical location of Panchor Area

Source: Rosman (2020) 
Panchor, the target of a new river-based tourism destination is a rural town strategically located next to Muar River and has Pagoh Education Hub for a neighbour. The Muar River flows next to Panchor, one of the major rivers flowing through the states of Johor, Negeri Sembilan and Pahang. So far Panchor has drawn only day-trippers who normally stop to savor local riverside restaurant delicacies. Many tourists opt for river cruises that take them closer to Muar City for a broader variety of river activities or even to other bigger cities across the border of the Johor state. However, Panchor must move forward as a tourist destination to draw more value-added tourists (2018). The city has to be revitalized into what it was like in the early 70 s - an administrative hub of the upper Muar River (Zakaria, 2020) with an important waterway between the West Coast and the Peninsula for traders that was central to the socio-economic status of the local community (Samah et al., 2011). Panchor's Muar River needs to be more for the local population than industrial fisheries. To do this, it needs to rope in the cooperation and involvement of the local community to promote local tourism to Panchor through a productive and sustainable tourism development project based on the river.

Tourism has grown today, and visitors are seeking more value for their vacations. Water tourism destinations are also becoming more popular nowadays, where visitors of the 21 st century view their vacations differently. They seem to look for different ways of travelling, to try new experiences and adventures, and to achieve higher holiday quality rates (Trono, 2014). Given these trends, river-based tourism may offer great potential to protect and maintain rivers as natural resources, as well as to revitalize and grow tourist destinations that emphasize sustainable and community-based tourism (Folgado-Fernández, Di-Clemente, Hernández- Mogollón, \& CampónCerro, 2019). In addition, the key aspect of water-based tourism today is one that has a natural environment, where people seek relaxation, leisure, and recreation (Jennings, 2016). The goal of this study is therefore to explore the possibility of a river-based tourism development plan for the Muar River in the rural town of Panchor. More significantly, it aims to investigate and assess the support and participation of the local community in the potential growth of Panchor's Muar River through river-based tourism.

\subsection{Literature Review}

\subsection{Underlying Theory}

Homans' Social Exchange Theory (SET) (Tittenbrun, 2012) infers the social behavior of Panchor's local community as an outcome of an exchange process. The theory focuses on the host group attitude and interpretation (Meimand et al., 2017). The theory also indicates that the relationship between the host community and the development tourism project is typically terminated if the costs outweigh the benefits. The confidence of residents is important as they are likely to be more willing to support the growth of tourism when they can benefit from tourism without having to incur additional costs (Homsud, 2017). To engage the local community in supporting tourism development activities intended for their region, a strong and positive perspective is needed. SET underlines various studies of tourism innovations such as Chuang (2010), Ward and Berno (2011), Paraskevaidis and Andriotis (2017), to name but a few. 


\subsection{Local Community's Support towards Tourism Development}

A local community is a structured tradition-based group made up of individuals and households residing in a given area (Kariuki, 2013). It refers to people who have also come together to share common resources within the region, thereby contributing similar sentiments, attitudes, expectations and aspirations towards the growth of tourism to some extent. Although support from local communities ensures the sustainability of the industry's commercial, socio-cultural, physiological, political, and economics (Alonso \& Liu, 2013; Dorcheh, \& Mohamed, 2013), their participation is vital in influencing the success of further development of tourism. According to Dorcheh and Mohamed (2013), scholars believe that community perception is a significant field of tourism study, as past studies (Diedrich \& García-Buades, 2009; Dorcheh \& Mohamed, 2013) have shown that community members are especially involved in the decision-making process when it comes to achieving sustainable tourism growth.

\subsection{Local Community's Attachment towards Tourism Development}

Community attachment refers to a person's thoughts, emotions, and a sense of belonging towards the town (Rasoolimanesh, Jaafar, \& Ahmad, 2017). It can be measured in a variety of ways, such as the duration of life or having been born or grown up in the group (Brida et al., 2014). In the analysis of the relation between group attachment and resident perception, literature shows a mixed result. Meimand et al. (2017) and Rasoolimanesh, Jaafar, and Kock (2015) argue that residents with stable feelings of attachment are more prone to the positive and negative effects of tourism, which affect their support for the development of tourism. Morales, Agüera, and Lópezguzmán (2018) have found a positive impact on the community's commitment to promoting tourism growth. The study shows that support for sustainable tourism growth for the local community depends on the degree of commitment people have to their neighborhood.

\subsection{Methodology}

\subsection{Research Design and Data Collection}

A qualitative approach to accessing the perception of local residents of a river-based tourism development center at Muar River in Panchor has been selected. Studies of Gnanapala and Karunathilaka attitude towards tourism development in 2016 showed that understanding community perception can provide decision-makers with useful insights into the growth of tourism, given that growth is largely dependent on stakeholders' ability to recognize threats, mitigate and adapt strategies and assess the implications of tourism development It is also proposed that the open-ended format be used to obtain various answers (Darb, 2006). Data were obtained from the Malaysian Department of Statistics (2011) on the 562 Panchor residents, whereas a purposeful sampling technique allowed the study to determine a recommended sample size of at least 226 residents (Krejcie \& Morgan, 1970) as the target respondents of an open-ended survey. A total of 17 numerators helped administer the survey questionnaire and treated inquiries from residents 
between March and April 2019. The study also conducted an interview with the Chief of Village Heads to expand data interpretation and complement the survey-gathered information.

\subsection{Data Analysis Procedure}

Both the open-ended questionnaire written responses as well as the interview transcripts were thematically analyzed. The material was then coded, interpreted and analyzed using grounded theory with the audio recordings of the interview transcribed. Then, the findings were interpreted accordingly.

\subsection{Results}

\subsection{Residents' Social Characteristics}

Of the 92 respondents of the survey, more than $71 \%$ of the Panchor villagers were males, while most of them were Malays (92\%). The two largest groups in the sample were $(23 \%)$ Gen X (3953 years old) and (41\%) Gen $Y$ (24-38 years old). Over half of the respondents $(60 \%)$ had completed high school and some had tertiary education. As for the occupational background, $27 \%$ were working in the public sector and $25 \%$ were from the private sector. Almost $46 \%$ of the respondents had resided in Panchor over the past 20 years.

The interview was conducted with Mr Khairunasir Md Zin, the Chief of Village Heads. Aged at 42 years old and lives in Muar, he holds a Diploma in Business Management and a Diploma in Teaching (personal communication, April 9 2019). His main tasks are to administer the 'mukim' (a subdivision of a district) and to oversee the development, security, unity, religion and welfare of the people as well as assisting the District Officer on rural project proposals. The Chief of Village Heads who had been in office since 2014 was interviewed for approximately 80 minutes. The whole session was audio-recorded with his consent. The survey responses showed that the majority of the residents (95\%) showed positive support and involvement in the future development of a river-based tourist centre in the village. Only $5 \%$ of them were negative towards tourism development. The questionnaire was written responses and interview transcripts which were analyzed thematically produced three interconnected themes: (1) community attachment, (2) economic gains and (3) environmental attitude.

\subsection{Community Attachment}

From a socio-cultural perspective, community involvement is expected to have a significant impact on local support for tourism development, particularly in rural areas (Meimand, et al., 2017). The local community displayed an inclination to support tourism development if they perceive the benefits of river-based tourism. Based on the positive written responses by the respondents, it was divulged that the future river-based tourism development could enhance the unity within the local community such as in facilitating 'group gains' which refers to the benefits accrued by the community (Cropanzano \& Mitchell, 2005). The youth local community, within the age group of 18 to 38 , revealed that as they were still physically active, they would love to participate in some of the river-based activities. They also thought that being involved in such 
activities would create not only unity within their small community, but also individuals who are open-minded and have a strong sense of belonging towards their community (Jaafar, Rasoolimanesh, \& Ismail, 2015).

Some local communities according to Morales et al. (2018) also displayed a negative attitude towards tourism development and the factors that could influence such a manner and perception could be demographic, personal, or social. A small inclination from a personal aspect, however, revealed that the local community would only be willing to support the development of tourism if everyone in the community worked together. Another respondent confessed that the community would support tourism development only if proper procedures were implemented particularly concerning the community's well-being and safety. Other written responses displayed a reluctance to be involved with river-based tourism due to old age. In contrast, some other older residents were content to be in their comfort zone and wanted only to attend to agricultural work on their fruit orchards.

\subsection{Economic Gains}

Residents who demonstrated great community attachment are more likely to make a crucial contribution to the development of sustainable tourism (Lee, 2013). The findings of this study unfolded respondents who displayed support towards tourism development in Panchor mainly because potential job opportunities for the locals could generate income and upgrade the local community's lifestyle. Table 1 below summarizes the written responses that are related to economic gains.

Table 1. Related to Economic Gains

\begin{tabular}{l} 
Respondents' Written Responses Summary \\
\hline Promote Panchor River locally and internationally \\
Create a new job opportunity \\
Opportunity to open-up new businesses \\
Can increase the local economy and introduce Panchor to the outsider \\
\hline
\end{tabular}

The findings revealed significant positive support and involvement of the Panchor residents in the development of river-based tourism that could enhance the community's economic gains. At the interview with the Chief of Village Heads, he mentioned that "new industries will create job opportunities and draw locals back to Panchor. It also attracts outsiders to come here." Hence, new jobs opportunities would be able to attract the youth of the local community to work within their local areas thus decreasing the number of people migrating to cities to seek jobs. Following this, the current development of the neighbouring regions of Pagoh Higher Education Hub, new housing areas, the future high-speed rail and other construction projects, all of which are also contribute to revitalising Panchor's economic status. Furthermore, the respondents suggested that the nearby river as a natural resource has great potential in attracting local and foreign tourists. Some of the responses were, "As a local resident of Panchor, I think that it is time to revive Panchor's unique river which has not been explored to its potential". Another resident said, "It can attract more local and international tourists".

However, some responses showed the residents' resistance to river-based tourism due to their concerns on the social and environmental well-being of the community. In summary, river-based 
tourism can help to promote Panchor although sustainability measures for a rural area should be considered as a priority by all relevant bodies. The new tourism industry could make Panchor village town known to other visitors and also attract local as well as international stakeholders to open up new business avenues.

\subsection{Environmental Attitude}

Another significant finding on the local community's attitude is the one relating to the environment. Table 2 below provides a description of some written answers extracted from the environmental attitude data. Respondents had a favorable view and attitude of their local area toward a riverbased tourism development when environmental awareness concerns were given priority. However, the results also showed resident knowledge of how an imbalanced local area growth could produce pollution, which could harm the river's cleanliness and natural beauty. As Homsud (2017) explains, a positive mindset is likely to emerge when one sees the benefits of tourism in the local area.

Table 2. Environmental Attitude

\begin{tabular}{l} 
Respondents' Written Responses Summary \\
\hline Create awareness to the local community to appreciate the \\
beauty \\
Awareness in maintaining the cleanliness of the river \\
Create pollution to the river \\
Destroy the beauty of the river \\
Create an imbalanced development \\
Can contribute to the cause ofpollution \\
\hline
\end{tabular}

The interview with the Chief of Village Heads revealed the optimistic attitude of the local community towards the growth of the village area's river-based tourism. He also indicated that the current and future development of Panchor's neighboring areas; Pagoh's Education Hub, HighSpeed Rail, Muar Furniture Hub and New Housing Areas could contribute positively to improving public services and creating new employment opportunities for residents. However, all parties directly or indirectly involved in construction activities must take responsibility for any changes that could interfere with the protection of natural resources or endanger the general well- being of the ecosystem around them (Amir et al., 2015).

\subsection{Discussion}

The preliminary findings of this study indicate that a river-based tourism development of the Muar River in Panchor may be just the right initiative to stimulate the residential area's very dull socioeconomic condition as well as promote sustainability. Being strategically placed next to Muar River allows Panchor the perfect host for tourists to take part in a variety of water-related activities. Such activities could attract more business opportunities that could potentially revive Panchor into the region's next lively, exciting, and new commercial hub.

The research also provides valuable details on the understanding of the host group and future participation in a development plan for water-dependent tourism. The results verified that the 
predicted social activity of the local community is an outcome of a process of exchange as theorized by SET. As they begin to recognize their new position as residents of a destination in the tourism industry, they become more conscious of the possible benefits and risks involved in their new social partnership with the visitors as well as the activities of development projects. The three themes that emerged from this study; local connection, economic benefits, and environmental attitude can be interpreted as positive expressions of the local community's mindset, support, and willingness to engage as partners in the creation of the river-based tourism center at Panchor. Furthermore, current and upcoming development projects around the Panchor region will give fresh impetus to further business investments, particularly those related to tourism from interested stakeholders within and outside the Johor state. A new vibrant economy also means a broader variety of opportunities for local youth who have left Panchor for work in bigger cities to take up.

\subsection{Conclusion}

This study's results could be summed up as helpful in three ways. Firstly, when promoting Muar River in Panchor as a tourist destination, this study could be the key guide for the Ministry of Tourism, Muar Municipal Council and Johor State Tourism Board. Second, Panchor's tourism destination initiative may be the next stimulus package for the economy of the local region and should be considered a high-priority state development project. Third, Malaysian tourism researchers should undertake a more in-depth sustainability analysis of Panchor as a waterbased tourist destination including maybe considering how universities within the Pagoh Education Hub should play a more collaborative role in reviving and sustaining the economy of Panchor.

This research is limited to only including the younger Panchor residents. Therefore, it is proposed that future studies encourage the older people, who are in fact the local community's key inhabitants, to contribute to a more inclusive and practical viewpoint of the potential growth of the city into a tourism destination. Future studies could also support their results by collecting the views of the neighboring towns of Pagoh and Gerisik, which could also experience some spill- over effects of rural area growth. Taken together, the study provides promising evidence that Panchor's river-based tourism growth is fully supported by the host community.

\section{Acknowledgement}

The authors would like to express special gratitude for the support received from 17 numerators of the Mags7 and M8-batch of the Tourism Department, Kulliyyah of Languages and Management who registered for the Transportation and Infrastructure in Travel Agency class in Semester 2, 2018/2019. The authors are indebted to Ms Siti Nur Hidayah Rosman for the location and site plans of Panchor. 


\section{References}

Alonso, A. D., \& Liu, Y. (2013). Local community, volunteering and tourism development: The case of the Blackwood River Valley, Western Australia. Current Issues in Tourism, 16(1), 47-62.

Amir, A. F., Ghapar, A. A., Jamal, S. A., \& Ahmad, K. N. (2015). Sustainable tourism development: A study on community resilience for rural tourism in Malaysia. Procedia-Social and Behavioral Sciences, 168(116-122).

Benjamin, N. (2018, December 10). Johor plans to develop more tourism products. Retrieved from https://www.thestar.com.my/metro/metronews/2018/12/10/johor-plans-to-develop-more-tourism-products/

Braun, V., \& Clarke, V. (2006). Using thematic analysis in psychology. Qualitative Research in Psychology, 3(2), 77-101.

Chuang, S. T. (2010). Rural tourism: Perspectives from social exchange theory. Social Behavior and Personality, 38(10), 1313.

Cropanzano, R., \& Mitchell, M. (2005). Social exchange theory: An interdisciplinary review. Journal of Management, 31(6), 874900

Darb, A. J. (2006). Evaluating training courses: an exercise in social desirability? Journal of European Industrial Training, 30 (3), 227-239.

Department of Statistic Malaysia (2011). Taburan Penduduk Mengikut Kawasan Pihak Berkuasa Tempatan Dan Mukim. Retrieved from https://www.mycensus.gov.my/banci/www/admin/uploads/penerbitanpdf/13.pdf

Diedrich, A., \& García-Buades, E. (2009). Local perceptions of tourism as indicators of destination decline. Tourism Management, 30(4), 512-521. http://dx.doi.org/10.1016/j.tourman.2008.10.009

Dorcheh, S. A., \& Mohamed, B. (2013). Local perception of tourism development: a conceptual framework for sustainable cultural tourism. J. Mgmt. \& Sustainability, 3,31.

Folgado-Fernández, J. A., Di-Clemente, E., Hernández-Mogollón, J. M., \& Campón-Cerro, A. M. (2019). Water Tourism: A New Strategy for the Sustainable Management of Water-Based Ecosystems and Landscapes in Extremadura (Spain). Land, 8(1), 2.

Gnanapala, A. C. (2016). Community Perception on Tourism Development and Its Impacts: a Study on Passikudha, Sri Lanka. Tourism, Leisure and Global Change, 3(2016), 164.

Homsud, N. (2017). The Effect of Residents' Attitude toward Tourism to Pro-Tourism Behavior: A Case Study of Hua-Hin.

Jaafar, M., Rasoolimanesh, S., \& Ismail, S. (2015). Perceived sociocultural impacts of tourism and community participation: A case study of Langkawi Island. Tourism and Hospitality Research. doi:10.1177/1467358415610373

Jennings, G. (2016). Water-Based Tourism, Sport, Leisure, and Recreation Experiences, 1-20.

Kariuki, P. N. (2013). Local residents' attitudes and perceptions towards tourism development: a study of lake Nakuru national park and its environs, Kenya (Doctoral dissertation, Moi University).

Krejcie, R. V., \& Morgan, D. W. (1970). Determining Sample Size for Research Activities. Educational and Psychological Measurement, 30(3), 607-610.

Laws, E., \& Semone, P. (2009). The Mekong: Developing a new tourism region. River Tourism, 55-74. 
Lee, T. H. (2013). Influence analysis of community resident support for sustainable tourism development. Tourism Management, 34, 37-46.

Md Zin, K. (personal communication, April 9, 2019).

Meimand, S. E., Khalifah, Z., Zavadskas, E. K., Mardani, A., Najafipour, A. A., \& Ahmad, U. N. U. (2017). Residents' Attitude toward Tourism Development: A Sociocultural Perspective. Sustainability, 9(1170), 1-29.

Morales, P. C., Agüera, F. O., López-Guzmán, T., \& Cuadra, S. M. (2018). Community Attachment and Support for Sustainable Tourism Development through the Attitudes of the Local Population: A Case Study in Puerto Plata, Dominican Republic. Mediterranean Journal of Social Sciences, 9(2), 173-184.

Paraskevaidis, P., \& Andriotis, K. (2017). Altruism in tourism: Social exchange theory vs altruistic surplus phenomenon in host volunteering. Annals of Tourism Research, 62, 26-37.

Rahman, N.H.A., Abas, S.A., Omar, S.R., \& Jamaludin, M.I. (2020). Exploring the river-based tourism product for Muar River: A tourism opportunity spectrum (TOS) approach. IOP Conference Series: Earth and Environmental Science, 447.

Rasoolimanesh, S. M., Jaafar, M., \& Ahmad, A. G. (2017). The effects of community factors on residents' perceptions toward World Heritage Site inscription and sustainable tourism development, 25(2), 198-216.

Rasoolimanesh, S. M., Jaafar, M., \& Kock, N. (2015). A Revised Framework of Social Exchange Theory to Investigate the Factors Influencing Residents' Perceptions. Tourism Management Perspectives, 16, 335-345.

Rosman, S.N.H. (2020). Geographical location of Panchor Area, Unpublished material, International Islamic University Malaysia

Samah, B. A., Sulaiman, M., Shaffril, H. A. M., Hassan, M. S., Othman, M. S., Samah, A. A., \& Ramli, S. A. (2011). Relationship to the River: The case of the Muar River community. American Journal of Environmental Sciences, 7(4), 362-369.

Shah, M. F. (2018, January 13). Johor now a top tourism destination. Retrieved from https://www.thestar.com.my/news/nation/2018/01/13/johor-now-a-top-tourism-destination/

Tittenbrun, J. (2012). The Theory of Social Exchange of G.C. Homans

Tosun, C. (2006). Expected nature of community participation in tourism development, Tourism Management, 27 (3) 493 504

Trono, A. (2014). Cultural and religious routes: A new opportunity for regional development.

Torres-Bagur, M., Palom, A. R., \& Vila-Subirós, J. (2019). Perceptions of climate change and water availability in the Mediterranean tourist sector. International Journal of Climate Change Strategies and Management.

Ward, C., \& Berno, T. (2011). Beyond social exchange theory: Attitudes toward tourists. Annals of tourism research, 38(4), 1556-1569.

Zakaria, B.K. (2020, May 3. Pancuran darah asal nama Panchor, Retrieved from https://www.bharian.com.my/hujung-minggu/kembara/2019/08/597255/pancuran-darah-asal-nama-panchor 